\title{
Analysis of Credit Risk Management in Small and Micro Businesses with Moral Hazard Model
}

\author{
Rao Yifei*
}

Dongbei University of Finance and Economics, No. 217 JianShan St., Shahekou District, Dalian, P.R. China 116025

\begin{abstract}
Small micro enterprises have effectively promoted the economic growth and technological innovation and created a lot of financial income for our country, which are not only the main force of the economic growth in our country, but also the basic cell and lifeblood of the economy in our country, however, financing difficulty that small micro enterprises suffer from is an inextricable problem which is hard to crack for a long time. Now, under the dual drive of the external competitive pressure and the assessment of internal profit, domestic commercial banks see it as an opportunity of business development and transformation to vigorously develop small micro credit business in succession, therefore, they enlarge the input of manpower, material resources and financial resources increasingly and aim to develop a vast new world in the small business. However, the credit risk problem of small micro enterprise has hindered the advance of commercial bank. Management of credit risk in small and micro enterprise will directly restrict healthy and rapid development of small credit business. Therefore, scientific and effective credit risk management for small and micro enterprise has become an imperative issue for domestic commercial banks to develop small credit business. This paper, based on moral hazard model, analyzes the deeply-rooted cause of the credit risk in small micro enterprise and further puts forward to the relevant strategies to solve the financing obstacles of small micro enterprise combining with domestic commercial banks' traditional experience in credit risk management.
\end{abstract}

Keywords: Credit risk management, financial market, banking system, micro enterprise.

\section{INTRODUCTION}

Financial market and banking system to small micro enterprise are imperfect in our country. Mean while, under than the small and micro enterprise generally lack mortgage assets and effective guarantee, the high risk in small micro enterprise operation conflicts with the principle of prudence in credit providers, as a result, credit providers generally hold a cautious attitude towards the lending proposition from small micro enterprise, and they even set higher access threshold and qualification requirement for credit clients with no collateral as credit guarantee. In a sense, this has not only led to the slow development of the small and micro credit business in credit institutions like banks, but also contributed to "financing difficulties" in the small micro enterprises.

\section{SMALL AND MICRO CREDIT BUSINESS AND CURRENT MANAGEMENT SITUATION}

\subsection{Definition to Small and Micro Enterprise}

Law of Promoting Small and Medium-sized Enterprises has clearly determined a definition to small and micro enterprise, which usually refers to small businesses, miniature enterprises, family workshops, individual industrial and commercial households.
In June 2011, the ministry, the national bureau of statistics, the national development and reform commission and bureau of finance jointly developed The Notice for Printing and Distributing the Type-dividing Standard of Small and Micro Enterprises, [1] in which small and medium-sized enterprise is further subdivided into three classes including micro, small and medium-sized three classes including micro, small and medium-sized enterprises according to the characteristics of its industry and a concrete type-dividing standard of small and micro enterprises is formulated according to the number of practitioners, total assets and annual revenue index of enterprises.

Since 2013, small and micro enterprises have accounted for an absolute majority of the main body of market [2]. The national small and micro enterprise development report promulgated by the state administration for industry and commerce in 2014 shows that by the end of 2013, the total number of all kinds enterprises reached up to 15.2784 million across the country. Among them, the number of small and micro enterprises was 11.6987 million, accounting for $76.57 \%$ of the total number of enterprises [3]. Figures show that China has a population of nearly 800 million labors, and the employment population reaches up to 767 million, micro and small enterprises have solved the problem of employment with 150 million people in our country, more than $70 \%$ of the new employment and re-employment is concentrated in a small and micro enterprises. At the same time, small and micro enterprises are mainly concentrated in the service industry and some high-tech industries, which has formed a good complementary and interactive relationship with large 
and medium-sized enterprises focusing on manufacturing, and perfected the market economic system and speeden the transformation of economic structure [4].

Comparing with the simultaneously repealed Provisional Regulations on Small and Medium-sized Enterprise Standards, the classification of the file to the small and mediumsized enterprise is more refined, in additional to small and medium-sized enterprises, the type of micro enterprise is also mentioned. In respect of division standard, the "notice" no longer takes the sales of enterprises as the basis [5]. Instead, it divides types of enterprise by measuring the operating income of the enterprise, which is more suitable for various industries.

Now, under the background that the macro economic environment is bad, small and micro enterprises' survival pressure is high, especially all kinds of social resources prefer to the large and medium-sized enterprises, which has limited the development of small and micro enterprises. So, small and micro enterprises are scarce in all aspects of the resources, and at the same time, because most of small and micro enterprises are in the market cultivation period with poor profitability, they must trust in multilateral cooperation to support the further development.

\subsection{Credit Risk of Small and Micro Enterprise}

Commercial banks will face a series of credit business risks different from traditional large and medium-sized enterprises to carry out the credit business in small and micro enterprises [6]. There are the following three aspects.

\subsubsection{Problem of Small and Micro Enterprise its Own}

Most small and micro enterprises have the following characteristics: high labor-intension, low technical content, poor management level and lacking independent innovation products, therefore, they can only rely on low prices in the market competition and are often disadvantaged in the market transactions. Such small and micro enterprises are hardly able to resist risk of market, what's worse, the change of environmental factors such as tight monetary policy will have a strong and violent impact on business operation.

The operators of small and micro enterprises mostly come from grass roots, so, the family mode of operation is fairly common and enterprises lack of long-term strategic vision, as a result, the phenomenon of pursuing short-term benefits is serious.

In additional to this, experience management and appointing people by favoritism give rise to the poor management level. The risk of moral hazard in the process of financing is quite obvious, which also exerts a large negative impact on the credit image of small and micro enterprise.

On the other hand, small and micro enterprises often have imperfect company management and false financial data, due to which banks can hardly see the internal truth clearly. This also increases the risk of credit.

Asymmetry information as well as the financing characteristics of small micro enterprises_-short, frequent and urgent, increases credit costs of financial institutions and brings a big obstacle to small and micro enterprises' financ- ing. What's more, the large number of small and micro enterprises, industry dispersion and different stages of development cause the diversity of small and micro enterprise financing needs, as a matter of course, financial institutions, in order to meet all kinds of financing needs from small and micro enterprises, also needs a variety of funding ways, which increases the cost of bank credit risk.

\subsubsection{Problem from the Government}

Government has yet to make effective fostering policy for the development of small and micro enterprise and establish special policy-related financial institutions offering small and micro enterprise financing service and financial support, so, the government fails to create a favorable external market environment and social service system for small and micro enterprises.

\subsubsection{Problem from Financial System}

Due to the special position of financial industry in national economy, the government has a strict system of rules designed specific to financial institutions so as to ensure the security of financial institutions and the stability of financial system and avoid adverse consequences due to financial crisis from the liquidity risk. The principle of prudence requires relevant departments to be strict with the risk threshold, which prevents small and micro enterprises from loaning from credit providers and losing good opportunities for development.

\subsection{Current Situation of Credit Risk Management in Small and Micro Enterprises}

Since 2011, due to the credit crunch, "financing difficulties" problem in small and micro enterprises become increasingly prominent, which has caused the close concern of the relevant departments, thus, the government has launched a number of policies and measures to promote and support the development of small micro enterprise. Commercial banks, small loan companies and guarantee companies, as ground executors of the country's credit policy, have been launching various financial services brands in succession directing at small and micro enterprises, such as "speed via credit" in Bank of Construction, "show and credit" in Bank of Communications, and "Mastery of China Bank" in Bank of China. These small and micro financial brands are distinctive and have played a huge role in promoting the development of small and micro enterprises and helping small and micro enterprises effectively reduce the financing cost.

Statistics of the people's bank show that at the end of 2014, small and micro enterprises' loan growth is picking up, and in the major financial institutions, small rural financial institutions and foreign banks, small and micro enterprises' loan balance is 15.46 trillion yuan, increasing $15.5 \%$ to compare with a year earlier. The speed of growth is $1.3 \%$ higher than that in the same period of last year, respectively 6.1 and $4.8 \%$ higher than those in large and medium-sized enterprises, and $1.9 \%$ higher than the general loan growth. At the end of 2014, small and micro enterprises' loan balance accounts for $30.4 \%$ of the loan balance, accounting for over $1 \%$ higher than that of last year. Small and micro enterprises' loans is in an increase of 2.13 trillion yuan for the 
Table 1. Customer hierarchies and basic price calculated by ping an Bank.

\begin{tabular}{|c|c|c|c|c|}
\hline Classification & Househol Net Asset & Credit Record & Basic Price & $\begin{array}{l}\text { Integrated Floating } \\
\text { Proportional }\end{array}$ \\
\hline First class & $>3000000$ & $\begin{array}{l}\text { Credit investigation: less than } 2 \text { times overdues } \\
\text { in } 2 \text { years and less than } 20 \text { days every time }\end{array}$ & $9.33 \%$ & $\begin{array}{l}\text { Base rate above } \\
\qquad 54 \%\end{array}$ \\
\hline Second class & $>2000000$ & $\begin{array}{l}\text { Credit investigation: less than } 2 \text { times overdues } \\
\text { in } 2 \text { years and less than } 20 \text { days every time }\end{array}$ & $9.51 \%$ & $\begin{array}{l}\text { Base rate above } \\
\qquad 57 \%\end{array}$ \\
\hline Third class & $>1500000$ & $\begin{array}{l}\text { Credit investigation: less than } 2 \text { times overdues } \\
\text { in } 2 \text { years and less than } 30 \text { days every time }\end{array}$ & $9.70 \%$ & $\begin{array}{l}\text { Base rate above } \\
\quad 60 \%\end{array}$ \\
\hline Fourth class & $>1000000$ & $\begin{array}{l}\text { Credit investigation: less than } 4 \text { times overdues } \\
\text { in } 2 \text { years and less than } 30 \text { days every time }\end{array}$ & $10.30 \%$ & $\begin{array}{l}\text { Base rate above } \\
\quad 70 \%\end{array}$ \\
\hline Fifth class & $>500000$ & $\begin{array}{l}\text { Credit investigation: less than } 6 \text { times overdues } \\
\text { in } 2 \text { years and less than } 30 \text { days every time }\end{array}$ & $10.91 \%$ & $\begin{array}{l}\text { Base rate above } \\
\qquad 80 \%\end{array}$ \\
\hline
\end{tabular}

whole year, which is more than 128.4 billion yuan compared with the percentage increase.

As the speed of global economic development slows down and the domestic enterprise management faces a bad environment, domestic banks further keep the good quality of assets by enhancing the level of risk management and upgrading the risk management measures, and improve the ability to resist risk through the optimization of its own risk management mechanism and upgrading of credit business, thus, small and micro enterprises' credit risk management has achieved good effect. Ping An bank, for example, keeps its non-performing loan ratio under $0.71 \%$ during the first quarter of 2014, whose risk ratio is significantly lower than that in the same industry. This suggests that Ping An bank risk has a set of relatively complete system in risk management, at the same time, in each loan, it also sets the a loan loss provision. Since last year, the loan loss provision has reached up to a total of 6 billion yuan, so further its capability of defending against risk is greatly enhanced. Table $\mathbf{1}$ below is the customer hierarchies and basic price calculated by Ping An Bank as shown in Table $\mathbf{1}$.

Table 2 is a list of the loan commitment from financial institutions to small and micro enterprises in 2015 according to the statistics in CSRC's official website.

Table 2. Loan commitment from financial institutions to small and micro enterprises in 2015.

\begin{tabular}{|c|c|}
\hline \multirow{2}{*}{ Time } & $\mathbf{2 0 1 5}$ \\
\cline { 2 - 2 } & The First Quarter \\
\hline \hline Financial institutes & 214132 \\
\hline Commercial bank & 159326 \\
\hline State-owned commercial bank & 55803 \\
\hline Municipal commercial bank & 32076 \\
\hline Joint-equity commercial bank & 36435 \\
\hline Rural commercial bank & 33039 \\
\hline Foreign banks & 1973 \\
\hline
\end{tabular}

\section{ANALYSIS OF CREDIT RISK MANAGEMENT IN SMALL AND MICRO BUSINESSES WITH MORAL HAZARD MODEL}

\subsection{Cause Analysis of Small Micro Enterprise Financing Obstacles}

Cost incurred in credit operations of commercial banks for small and micro enterprise mainly includes two parts: cost of information and cost of agency.

\subsubsection{Cost of Information}

Here, the so-called information cost refers to the collection of cost in the process of investigation, identification and confirmation of qualified loan customers.

Compared to large and medium-sized enterprises, banks should give more information cost for small and micro enterprises, which is mainly due to the following reasons:

First, there are a great number of small and micro enterprises that haven't set up perfect enterprise credit system, which causes commercial banks to incur more cost in searching and investigating the highly qualified small and micro enterprises. Second, most small and micro businesses are family-owned or individually-owned, so, enterprise is only responsible to the owner, which further increases the cost of commercial banks to understand the status of the small and micro enterprises. Third, bankruptcy rate of small and micro enterprise is high. In order to survive in the harsh competition, small and micro enterprises rarely take the initiative to strengthen their own credit construction and even will still have forged management and financial records, such behavior makes it commercial banks cost more to identify the real situation of enterprises.

\subsubsection{Cost of Agency}

Here the agency cost refers to the cost of supervision and constraint to ensure the recycling of loan principal and interest on loans after the establishment of the debtor-creditor relationship.

Similar to information cost, agency cost in small and micro enterprise is also higher than that of large and mediumsized enterprises, this is because: 
First, bankruptcy risk in small and micro enterprise is bigger, if it is so, they have no ability to repay the loan defaults, so, banks must monitor the change of the small and micro enterprises at any moment. Second, small and micro enterprise operation is not standard and financial information is chaos, banks must spend more cost identifying the real operating conditions and confirming the repaying ability.

Both information cost and agent cost are caused by asymmetry information, the high cost caused by which is the root cause of the financing difficulties in small and micro enterprises. The generally believed reason, lack of collateral, is the external performance of the fundamental reason for financing difficulty in small and micro enterprises, which is the non-price condition that banks reduce the transaction costs of loan, and small and micro enterprises will be rejected by banks if they cannot meet the non-price condition.

This paper will use Jean Tirole's moral risk model to explain the non-price condition. Suppose an entrepreneur needs to invest in a project, the total investment for the fixed project is $I$, the total available fund of the entrepreneur is $A(A\langle I)$, and the rest needs gaining through external financing. If the project is successful, the total income that the entrepreneur can obtain is $R$; If the project fails, it won't generate income. Project is constrained by the moral risk, if the entrepreneur puts more effort, the success probability of the project is $P_{H}$, on the contrary, if the entrepreneur puts less effort, the success probability of the project is $P_{L}$. The total profits are shared by the entrepreneur and the external investor, in which the entrepreneur gains $R_{b}$, and the external investor gain $R_{1}$.

If the entrepreneur puts less effort, the individual income he has is $B$. For convenience, assuming that entrepreneur and external investor both have equally moderate risk, the yield rate is equal to the risk-free rate of interest (the riskfree rate of interest is 0 ). According to the condition of incentive compatibility, to enable the entrepreneur to put more efforts rather than put less effort, there must be established a formula as follows.

$P_{H} \cdot R_{b} \succ P_{L} \cdot R_{b}+B \Rightarrow\left(P_{H}-P_{L}\right) \cdot R_{b} \succ B$

in which $\left.\Delta P=\left(P_{H}-P_{L}\right), \Delta P \cdot R_{b}\right\rangle B$ refers to the total income of the entrepreneur, namely, the least value of $R_{b}$ is $B / \Delta P$, now, it shows the total income of the external investor $\mathrm{R} 1$ has its maximum value as

$R_{1}=R-R_{b}=R-\frac{B}{\Delta P}$

Considering the success possibility of the project, the warrantable prospective income $\mathrm{P}$ is:

$$
P=P_{H} \cdot\left(R-\frac{B}{\Delta P}\right)+\left(1-P_{H}\right) \cdot 0=P_{H} \cdot\left(R-\frac{B}{\Delta P}\right)
$$

As the revenue-producing institute in market, the external investor will loan fund to the entrepreneur if the warrantable prospective income $\mathrm{P}$ is higher than circulate necessary fund $I-A$.

$$
P_{H} \cdot\left(R-\frac{B}{\Delta P}\right) \succ I-A
$$

If $A=\bar{A}$, the warrantable prospective income is just to be the initial loan.

$$
\bar{A}=P_{H} \cdot \frac{B}{\Delta P}-\left(P_{H} \cdot R-I\right), \bar{A} \text { here is the non-price }
$$

condition in financing process.

Only if successful entrepreneurs hold more than loan, they can take out a loan from fund raising institutions. Lack of collateral, therefore, is not the root cause of the financing difficulty in small and micro enterprises. Instead, the fundamental reason is that banks and other financial institutions bear the transaction costs for loans to enterprises, in order to reduce their transaction costs, they set collateral as non-price condition.

\subsection{Ways to Solve Financing Obstacles from Transaction Cost Perspective}

For small and micro enterprise groups with different characteristics, this paper proposes different financing ways to reduce transaction costs in the process of financing and promote the development of small and micro enterprises.

High-qualified and technology-based small and micro enterprises should be encouraged to face a wider capital market and enter the securities market through direct financing. Through the market supervision and standardization of the business behavior such as information disclosure, the transaction costs of financing can be reduced in the market.

For some small and micro enterprises which have regular business with large enterprises, the large enterprises' supply chain financing is a better choice. Large enterprises' orders and payment vouchers to the small and micro enterprises can become collaterals in financing process, which enables small and micro enterprises to satisfy financial institutions' nonprice conditions and reduces the transaction cost in financing process.

Small and micro enterprises without any characteristics have no way to reduce the transaction costs, but they can develop relational financing. Through long-term and stable contacts with the bank, the long-term relationship can be established and transaction costs can also be reduced.

\section{CONCLUSION}

To sum up, under the condition of market economy, if small and micro enterprise itself doesn't conform to the standard of financial institutions, banks and other financial institutions, as main bodies of self-sustaining economy, will reduce small and micro enterprise loans. Although the government can guide financial institutions to provide services 
to small enterprises through a variety of policies, it cannot make up for the high-risk loans to small enterprises because the effect of the policy is limited. Therefore, under the market economy rule, small and micro enterprises' financing difficulties can be really solved if they constantly improve their own quality. Only small and micro enterprises have a sustainable and healthy development, they are likely to enhance their accumulation of market power and get direct financing in the capital market.

\section{CONFLICT OF INTEREST}

The author confirms that this article content has no conflict of interest.

\section{ACKNOWLEDGEMENTS}

Declared none.

\section{REFERENCES}

[1] A. N. Berger, R. J Rosen, and G.F. Udell "The effect of market size structure on competition: The case of small business lending", Board of Governors of the Federal Reserve System Working Paper, 2001

[2] J. Tirole, "Principles of corporate finance", China Renmin University Press , 2007.

[3] H. Qi, "Small financial service system construction", Finance, vol 11, pp. 64-66, 2010.

[4] W. Yancheng, "Small and micro enterprise credit risk and countermeasures", China Collective Economy, 2012, vol. 28, pp. 91-92.

[5] Z. Guoxin. "SME financial support system effectiveness research", Zhejiang University Press, 2007.

[6] C. Xiaohong, "Small and medium-sized enterprise financing and governance", Economic Science Press, 2011.

Received: June 10, 2015

Revised: July 29, 2015

Accepted: August 15, 2015

(C) Rao Yifei; Licensee Bentham Open.

This is an open access article licensed under the terms of the (https://creativecommons.org/licenses/by/4.0/legalcode), which permits unrestricted, noncommercial use, distribution and reproduction in any medium, provided the work is properly cited. 